\title{
Delay Impact of COVID-19 Pandemic on Malaysian's Oil and Gas Projects
}

\author{
Hissein Djibrine Abdelrassoul ${ }^{1}$, Dr Zulhasni Bin Abdul Rahim ${ }^{2}$ \\ ${ }^{1}$ Postgraduate Student, Project Management, Faculty of Civil Engineering, UTM \\ ${ }^{2}$ Senior Lecturer, Malaysia-Japan International Institute of Technology (MJIT), UTM
}

\begin{abstract}
COVID-19 pandemic has extremely affected people and businesses around the world. Oil and gas industry are not exempted, and negatively impacted by the unprecedent crisis of COVID19. This pandemic has also caused delays in the oil and gas projects. In an attempt to control the spread of COVID-19, Malaysian government has introduced Movement Control Order (MCO) in the whole country to be closed and lockdown all premises except essential services to operate. This has resulted major delays in the project execution. Researchers have conducted studies to identify factors that causing project delays. Approximately 75 delay factors were found from previous studies and it revealed that most delay factors were not caused by COVID19. In the current research, the delay factors due to COVID-19 were identified and some delay factors were found to have similarity with literature. Additionally, interview sessions were organized with oil and gas professionals involving in the oil and gas industry. Delay factors due to COVID-19 and mitigation strategies were identified from the interview sessions. Moreover, this result has used in the designing of survey questionnaire and distributed to project practitioners working in the oil and gas industry in Malaysia. 110 Oil and gas professionals include 52 Clients, 25 consultants, 23 contractors, 5 subcontractors and 5 vendors/suppliers have participated in the survey. Data collected from survey was analyzed and interpreted by means of median and Relative Importance Index (RII). Based on this information, delay factors and mitigation strategies were ranked according to their importance and impact to project. It is observed that the higher value of the RII the more critical cause or impact factor. Top seven (7) delay factors were identified and top seven (7) mitigation measures were proposed as recommendations for future implementation in the oil and gas project.
\end{abstract}

Keywords: COVID-19, Oil and Gas, Relative Importance Index (RII)

\subsection{Introduction}

Coronavirus Decease (COVID-19) was declared as an outbreak of public health emergency of international concern on $30^{\text {th }}$ January 2020 and a pandemic on $11^{\text {th }}$ March 2020 (WHO,2020). Globally, COVID-19 pandemic has extremely affected people and impacted all type of businesses in the public and private sector. The oil and gas industry are not exempted, and it has been negatively impacted by this unprecedent crisis of COVID-19 pandemic. Moreover, the oil and gas industry are facing challenges such as disruption of material and equipment supply, shortage of workforce on site and financial crisis (Yaser \& Abdulsalam , 2020). In response to the crisis, many oil and gas organizations have implemented short term strategies such as cost- 
cutting, downsizing and renegotiating contracts in order to reduce cost and control expenses. For instance, rationalizing is one of the factors that has led to countless employees to lose their job during this pandemic.

Furthermore, COVID-19 pandemic has also caused delays in the oil and gas projects. Delay of a project is defined as behind project completion as compared to the baseline schedule. Delay causes risk to a project objective related time, cost and quality (Umeesh et al., 2018). Most construction delays were generally the outcome of miscommunication among contractors, subcontractors, owners and suppliers (Aditi, 2014). Additionally, delay factors such as "lack of proper planning, budgeting, and scheduling, scope creep, and late delivery of materials" have reported by Reyadh and Saad (2019).

Many researchers have conducted studies to identify factors that causing project delays not related COVID-19. However, in this current investigation, the focus is to analyze project delay impact due to COVID-19 pandemic which is an unprecedented risk event that is unknown to project stakeholders. The investigation is mainly identifying potential factors that causing project delays due to COVID-19. Furthermore, interview sessions were organized with oil and gas professionals who have many years of working experience in the oil and gas industry.

Moreover, the result from the interview sessions has used in the designing of survey questionnaire and distributed to project practitioners working in the oil and gas industry in Malaysia. Collected data was analyzed and interpreted based on the median and Relative Importance Index (RII). Findings showed top seven (7) delay factors and its impact were identified. Additionally, top seven (7) potential mitigation measures were proposed as recommendations for future implementation in the oil and gas project.

\subsection{Problem Statement}

COVID-19 outbreak has dramatically impacted people and all type of businesses around the globe. The spread of Coronavirus Disease 2019 (COVID-19) is causing unprecedented delays, business disruptions and uncertainty on project executions. Travel limitations, social distancing and quarantines are progressively disrupting supply chains, contractor and subcontractor workforces and the availability of key personnel for project inspections which lead to project delays and increased costs.

The oil and gas industry are an important sector for the Malaysian economy's growth and has contributed significantly to the development of the country. In an attempt to control the spread of COVID-19 pandemic, the Malaysian government has introduced Movement Control Order (MCO) in the whole country to be closed and lockdown all premises which include public and private sector and allowing only essential services to operate such as banking and finance, water and electricity, healthcare and medical, telecommunication and food supply. This has resulted in disrupting all type of businesses with no exception to oil and gas industry. Malaysian oil and gas industries are currently facing major challenges in executing their planned projects at different stages which lead to deferment or project delay. For instance, giant oil and gas 
player PETRONAS, Malaysian state energy has reported that the risks of delays to numerous projects were growing due to extended coronavirus related lockdowns locally and around the world. Additionally, Malaysia's largest oil and gas services company Sapura Energy stated that the company has faced a delay in projects due to the widespread coronavirus shutdowns. Project delay is one of the significant challenges faced by many oil and gas projects.

It is vital to investigate and analyze the delay impact of the COVID-19 pandemic crisis on Malaysian oil and gas project. This research, therefore, has the purpose to seek determining the significant risk factors causing delay on project schedules that may lead to cost overruns and poor quality in construction projects related to the oil and gas sector in Malaysia. The objective of this investigation is to identify the delay factors which affect the project's completion.

\subsection{Research Questions}

The study investigates the factors causing delays in oil and gas projects in Malaysia due to the impact of COVID-19. Identification of potential delays factors impacting project performance will be performed through comprehensive literature reviews and feedback from oil and gas industry experts with more work experience exposed to oil and gas projects in Malaysia.

(1) What are the challenging factors in the delay of oil and gas projects in Malaysia and globally?

(2) What are the impact factors in the delay of oil and gas projects in Malaysia during COVID19 crisis?

(3) What are the proposed mitigations and recommendations for future implementation in the construction of oil and gas projects in Malaysia?

\subsection{Research Objectives}

In order to accomplish the analysis of the problems mentioned above, the objectives of the research are as follow:

(1) To investigate and identify unpredicted factors causing delays in oil and gas projects in Malaysia due to the impact of COVID-19 through comprehensive literature reviews, interviews and survey questionnaires

(2) To assess and analyze the factors causing oil and gas project delays related to COVID-19

(3) To interpret the findings and rank top seven (7) delay factors and its impact and propose top seven (7) potential mitigation measures as recommendations for future implementation in the oil and gas projects

\subsection{Scope of Study and Limitation}

This investigation will be mainly focusing on identifying factors causing delays in oil and gas projects in Malaysia due to the impact of COVID-19. Focus group and individual interviews will be carried out in order to determine the relevant factors causing delays. Additionally, the set of design questionnaire surveys will be conducted to collect data from oil and gas industry experts with project management background. Experts include project directors and managers, 
project engineers, planners, supervisors, contractors, and subcontractors working in oil and gas projects in Malaysia. Qualitative approach will be adopted to analyze the delay impact of oil and gas projects in Malaysia. Lastly, it is to interpret the findings and to propose potential recommendations to be implemented by Malaysian Oil and Gas project practitioners.

\subsection{Significant of Study}

The Malaysian oil and gas industry are facing challenge due to the impact of the coronavirus disease 2019 (COVID-19) pandemic. The Malaysian government has introduced Movement Control Order (MCO) in the entire country to be closed and lockdown all premises except essential services to operate. This has led to unprecedented delays, business disruptions and uncertainty on project executions. Moreover, travel limitations, social distancing and quarantines are progressively disrupting supply chains. Additionally, contractor and subcontractor workforces have been impacted for executing project which further led to delays and increased costs. Project delay is one of the significant challenges faced by many oil and gas projects. Therefore, it is important to investigate and analyze the impact of the COVID-19 pandemic crisis in the Malaysian oil and gas project.

\subsection{Literature Review}

\subsection{Impact of COVID-19 Pandemic around the World}

Globally during the pandemic, the situation has extremely declined by firstly lack of material supply which impacted the construction industry (Yaser \& Abdulsalam, 2020). Decline in oil and gas prices, lockdown and movement restriction across many countries have delayed countless of oil and gas projects which are complex projects that rely on workforce and materials around the world. To break the spread of COVID-19 chain, many nations around the globe started executing some control measures to decrease the movement of individuals which has negatively affected the construction industry as it requires site work and all project team member should be available to work, inspect, check, monitor and control all site activities. Additionally, retrenchment is also one of the major crises during the pandemic situation. Worldwide, millions of workforces have lost their jobs due to COVID 19 disaster. In the construction business, most workers lost their jobs as the small enterprises are incapable to pay salaries during lockdowns (Yaser \& Abdulsalam, 2020).

The current pandemic of COVID-19 has caused challenges to Malaysia government which has led to first Movement Control Order (MCO) in Malaysia on 16th March 2020. In an attempt to control the spread of COVID-19, the whole country has been ordered to close and lockdowns all premises include government and private sector. This has resulted in disrupting all type of businesses with no exception to oil and gas industry and allowing only essential businesses or services such as banking and finance, water and electricity, healthcare and medical, telecommunication, food supply. This Movement Control Order (MCO) has been observed by all stakeholders in the construction industry include general workers, developers, and suppliers of construction material. Furthermore, any breach of the MCO by stakeholders will result in penalties for failing to comply with the regulations. This has led to many corporations are now finding it difficult to keep up with their monthly operating costs ("The financial impact of 
COVID-19”, 2020).

\subsection{Impact of COVID-19 Pandemic on Malaysian Oil and Gas Industry}

The restrictions on movement of order have drastically and immediately impacted the Malaysian oil and gas projects. The oil and gas industry are one of typical industry that requires physically on-site involvement by all the project stakeholders include project team members, contractors, subcontractors and suppliers. Therefore, it is important to highlight how this industry has been impacted and addressed this unexpected crisis. Malaysian oil and gas industries are struggling with major challenges in executing their planned projects at different stages which lead to deferment or project delay. For example, PETRONAS, giant oil and gas player of Malaysian state energy has reported that the risks of delays to many projects were increasing due to extended coronavirus related lockdowns locally and around the world ("Firstpost Business", 2020).

Additionally, another such as Company Sapura Energy is of the Malaysia's largest oil and gas services stated that the organization has faced a delay in projects due to the widespread coronavirus shutdowns ("Energyworld", 2020). Another example, Hibiscus Petroleum has also taken strong measures to stop the spread of COVID-19 and minimize the impact on its operations offshore in Malaysia and UK central North Sea ("Offshore Business, 2020).

Furthermore, the improvements in global oil prices and easing of COVID-19 lockdowns will rebound the upstream activities in spending and taking risk appetite in 2021 compare to 2020's lows. For instance, PETRONAS and subsidiaries have huge financial investment burden for mega project RAPID. The delayed of starting up the operation of RAPID project to process $300,000 \mathrm{barrel} /$ day of crude in 2021 will have a significant crude deficit for Malaysia, which require to accommodate mostly through imports as domestic production struggles ("Malaysia Oil \& Gas Q1 2021", 2020). Project delay is one of the significant challenges faced by many oil and gas projects.

\subsection{Project Management Triangle Concept}

Generally, in project management; any project is required to be evaluated under the triple constraints which include the cost, time and quality or scope. Hence, identifying the project drivers at early stage to ensure project success is crucial. In reality, the key project management problems include cost, time and quality, have become the main reasons for assessing project management performance over the years ( Aris et al., 2015).

Time and cost are commonly selected for measuring the project performance while quality has been considered as outcome from people's perception and beliefs which often changes over the life cycle of a project (Aris et al., 2015). In any aspects the oil and gas sector, efficient project execution is a primary business target. Businesses expected a great deal from staffs who have a mix of qualities that would support the organization and ultimately contribute to the financial performance of their companies ( Aris et al., 2015). 
One of the success factors in project management applicable to oil and gas companies is successful teamwork which is expected to have a mixture of technical skills, experience and general abilities to carry out a project. (Aris et al., 2015). Employers are actively targeting skills such as problem solving, communication, teamwork, interpersonal, social and time management as key criteria for employability, especially in team environments. Collaboration and strong relationship are regularly reinforced by managers as vital skills that are very important in the working world. ( Aris et al., 2015). Figure 1 below shows project management golden triple adopted by any project (The project management blueprint, 2019).

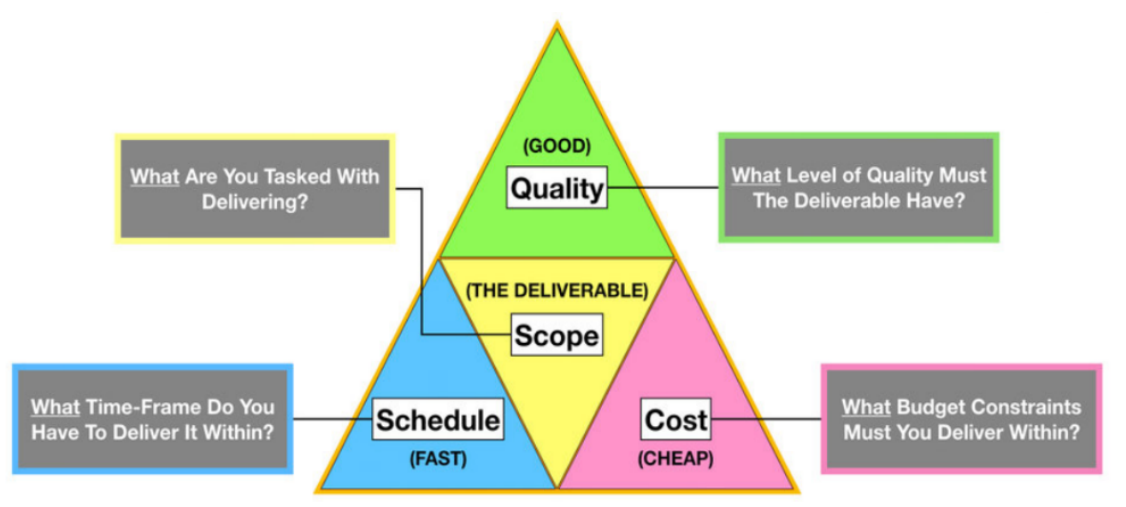

Figure 1 - Scope and the Triple Constraints of Quality-Time-Cost

\subsection{Previous Studies Conducted on Factors Causing Project Delays}

Delays are a common risk faced by construction industry and oil and gas industries are no exception. Oil and gas projects have a long development cycle, massive financial obligations and endless uncertainties that could have a major impact on project completion. There are different causes of delay, some of which are common in most projects, such as lack of detailed planning and poor project management, and others that are unique to certain projects which depending on the requirements and strategy aspects (Umeesh et al., 2018).

Literature and experience have both indicated that any project should be accomplished prior to agreed completion dates and within budget in order to be successful construction projects (Aliyeh et al., 2018). Consequently, identification for causes of delay related time are considered critical importance to the success of construction projects. Many investigators have identified list of factors that impact the delay in construction projects which will affect the performance of the company as well as overall economy of the nation (Aliyeh et al., 2018). The main factors causing delay in construction projects are commonly associated with the performance triple constraint include time, cost, and scope (Aliyeh et al., 2018).

In order for construction projects in oil and gas industries to be successful," it is extremely critical that the risks affecting projects are carefully observed, the causes and characteristics of risks are deeply evaluated to assist the project team to propose most suitable and realistic strategies to mitigate those risks "(Thuyet et al.,2007). Studies have been carried out to 
investigate the factors causing delays in pipeline construction of oil and gas projects by Reyadh \& Saad (2019) have identified list of 47 delay factors causing to the project failure, some factors include "poor management skills, slow decision-making within all project teams; lack of proper communication between contractor, consultant and client; inadequate design team; variations in scope; unrealistic contract decision-making and delay in project preparation drawings". Similar study conducted on the cause of during construction phase, the findings stated total of 47 identified elements which have caused the delay and categorized into different group include client, project, contractor, engineering, external, and resources (Umeesh et al., 2018).

In addition, seven (7) other major causes of delay were discovered in Oman on oil and gas construction projects in the study conducted by Ruqaishi and Bashir (2013). The factors were identified include insufficient planning and scheduling of the project by contractors; difficulties with subcontractors, lack of site management and supervision by contractors; lack of management of contractors 'schedules; late in delivery of materials; lack of communication effective among project stakeholders; and lack of interaction with vendors in the engineering and procurement phase. Other findings from similar study conducted on construction delay of projects in peninsular Malaysia, the delay factor identified include lack of detailed planning of work, lack of dedicated leadership and management, as well as lack of effective communication structure (Memon et al., 2014).

Another Study conducted in Egypt on the factors causing delay in oil and gas projects, the results were due to financial risks from lack of project financing, easy-going government regulations and policies, as well as lack of project budget (Akal, 2016). Similar investigation conducted in Australia reported that the delay factor due to financial issues is due to economic constraints on upstream businesses from the decline in oil price (Klinger, 2016). Additional type of delay identified in Iran related to political, administration policies, and inter-government rules as well as the delay in buyback problems due to bidding process is suspended (Tippee , 2017). Alike to oil and gas projects around the world, Malaysia's oil and gas projects are also delayed due to factors include late agreement's acceptance and financial limitations on upstream businesses due to decline in oil price, pending government decisions and changes in project scope (Umeesh et al., 2018).

A study reported by Chandra (2015), all risk factors should be explored and response strategies should be improved in order to manage risks for all construction project stakeholders; the risk factors influencing the progress of projects should be investigated. Additionally, risks in construction projects have many negative impacts on any country. Five effects of construction risk factors include time overruns, cost overruns, poor quality and stop the project were identified (Chandra, 2015). An investigation conducted in Abu Dhabi at EPC stage, the most major causes of delay in oil and gas project were discovered as late in procurement and delivery, inadequate selection of contractors in the planning and EPC phases (Salama et al.,2008) According to Thuyet et al. (2007) reported results from a survey to find the risk factors affecting the construction of oil and gas projects in Vietnam, list of five factors were 
identified as the main causes of project delay which include long project approval procedures and bureaucratic government systems, internal approval processes from the owners, incompetence of project teams, poor design and inadequate tendering practices. Regardless of the oil and gas industry, it is clear that none of the above factors can be considered unique to projects in oil and gas construction but these factors are general that could cause delays in any project. Another study conducted by Jergeas and Ruwanpura (2010) on the factors causing cost and schedule overruns were listed as misplaced optimism, misguided objectives, misaligned strategies, misdirected execution, and missing links.

Furthermore, a case study conducted on a petroleum oil refinery project in central India, to identify the risk factors influencing time, cost, and quality using a cause-and-effect diagram. The outcome showed that technology, scope change, engineering and design change, and implementation methodology selection were the major factors influencing time, cost, and quality (Dey, 2012). And those factors were resulted from different categories include technical risks, economic and financial risk, political risks, organizational risks, natural hazards and statutory clearance risks.A published report by Offshore Magazine stated that the complex mega-projects worth approximately USD 230 billion in oil and gas projects have been postponed due to some causes related to subsurface challenges, government red tape, delays in agreements and financial limitations due to drop in oil price on upstream business ("Offshore Magazine, 2016). The link between the successful construction project and the risk factors are to be identified through careful assessment effect on the key drivers of the project which are the cost and schedule as well as the quality (Mukhtar et al., 2019).

Delay in project and cost overrun are the most serious problems faced oil and gas industries. Samarah and Bekr (2016) have classified delays into two categories include internal causes and external causes. Any factor associated with parties within the contract is considered internal delay factor while any factor interrelated to reasons beyond the contract is treated as external delay factor. Alternative study conducted on the construction sites in Jordan, the results revealed that there were 22 significant factors identified with the cause related to client, contractor and consultant ( Samarah \& Bekr , 2016). Additionally, the factors were ranked from most significant factors to least significant factors of delay.

As reported by Sambasivan \& Soon (2007), in their investigation total of 10 most important causes of delay were identified include (1) contractor's improper planning, (2) contractor's poor site management, (3) inadequate contractor experience, (4) inadequate client's finance and payments for completed work, (5) problems with subcontractors, (6) shortage in material, (7) labor supply, (8) equipment availability and failure, (9) lack of communication between parties, and (10) mistakes during the construction stage. Furthermore, list of identified significant factors of project delay from comprehensive literature has been categorized under 10 Knowledge areas of The Project Management Body of Knowledge (PMBOK 6th edition, 2017). Table 1 summarizes the consolidated list of factors impacting oil and gas project delays from literature review. 
Table 1 - Factors Impacting Oil and Gas Project Delays from Literature

\begin{tabular}{|c|c|c|}
\hline $\begin{array}{l}\text { Knowledge } \\
\text { Areas }\end{array}$ & $\begin{array}{l}\text { Factors impacting oil and gas project delays from } \\
\text { literature }\end{array}$ & Sources \\
\hline $\begin{array}{c}\text { Project } \\
\text { Integration } \\
\text { Management }\end{array}$ & 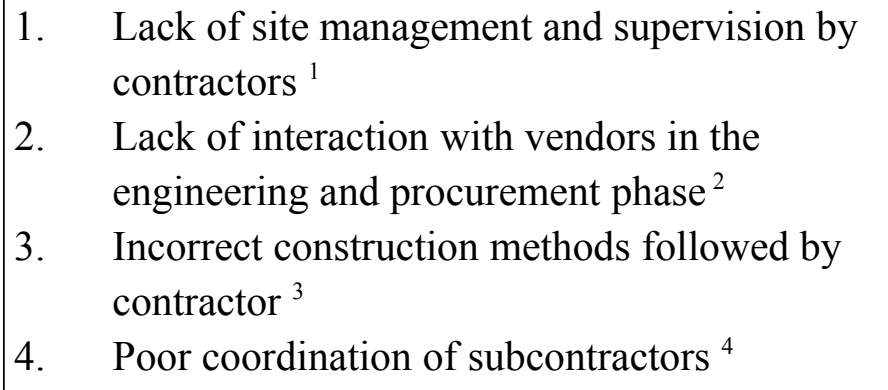 & $\begin{array}{l}\text { Ruqaishi \& Bashir, } \\
\qquad(2013)^{1,2} \\
\text { Samarah \& Bekr, } \\
(2016)^{3} \\
\text { Umeesh et al., } \\
(2018)^{4}\end{array}$ \\
\hline $\begin{array}{l}\text { Project Scope } \\
\text { Management }\end{array}$ & $\begin{array}{l}\text { 5. Change in project scope }{ }^{1} \text { and client's changes } \\
\text { of the design }{ }^{2} \\
\text { 6. Changes in the original design by consultant }{ }^{3} \\
\text { 7. Scope creep }{ }^{4} \\
\text { 8. Underestimating the complexity of projects }{ }^{5}\end{array}$ & $\begin{array}{l}\text { Reyadh \& Saad } \\
(2019)^{1,4} \\
\text { Umeesh et al., } \\
(2018)^{1,5} \\
\text { Dey, }(2012)^{2} \\
\text { Samarah \& Bekr } \\
(2016)^{2,3}\end{array}$ \\
\hline $\begin{array}{c}\text { Project } \\
\text { Schedule } \\
\text { Management }\end{array}$ & $\begin{array}{l}\text { 9. Lack of detailed planning and scheduling of } \\
\text { the project by contractor }{ }^{1} \\
\text { 10. Delay in project preparation drawings }{ }^{2} \\
\text { 11. Lack of management of contractors' schedules } \\
\text { 3 } \\
\text { 12. Time overruns }{ }^{4} \\
\text { 13. Progress payments are not made in the time by } \\
\text { the client }{ }^{5} \\
\text { 14. Delay due to sub-contractor's work }{ }^{6} \\
\text { 15. Delay in approving major changes in scope of } \\
\text { 16. Unrealistic project duration }{ }^{8} \\
\text { 17. Ineffective ways of monitoring and feedback }\end{array}$ & $\begin{array}{c}\text { Reyadh \& Saad } \\
(2019)^{2} \\
\text { Ruqaishi \& Bashir, } \\
(2013)^{1,3} \\
\text { Memon et al., (2014) } \\
\text { Chandra, (2015) } \\
\text { Samarah \& Bekr, } \\
(2016)^{4,5,6} \\
\text { Umeesh et al., } \\
(2018)^{7,8,9}\end{array}$ \\
\hline $\begin{array}{l}\text { Project Cost } \\
\text { Management }\end{array}$ & $\begin{array}{l}\text { 18. Lack of project budget }{ }^{1} \\
\text { 19. Cost overruns }{ }^{2} \\
\text { 20. Cash flow and financial difficulties faced by } \\
\text { contractor }{ }^{3} \\
\text { 21. Changes in the cost of resources (labor, } \\
\text { material and equipment) }{ }^{4} \\
\text { 22. } \text { Financial difficulties of the owner }^{5} \\
\text { 23. Escalation material prices }{ }^{6} \\
\text { 24. } \quad \text { Underestimating of project cost }^{7}\end{array}$ & $\begin{array}{c}\text { Akal, }(2016)^{1} \\
\text { Chandra, }(2015)^{2} \\
\text { Samarah \& Bekr, } \\
(2016)^{2,4} \\
\text { Umeesh et al., } \\
(2018)^{3,5,6,7}\end{array}$ \\
\hline
\end{tabular}




\begin{tabular}{|c|c|c|c|}
\hline $\begin{array}{c}\text { Project } \\
\text { Quality } \\
\text { Management }\end{array}$ & $\begin{array}{l}25 . \\
26 . \\
27 . \\
28 . \\
29 . \\
30 .\end{array}$ & $\begin{array}{l}\text { Poor quality }{ }^{1} \\
\text { Error in design and contract documents by } \\
\text { consultant }{ }^{2} \\
\text { Rework due to mistakes during construction } \\
\text { by the contractor }{ }^{3} \\
\text { Technical issues faced by contractor }{ }^{4} \\
\text { Drawings are not efficient enough provided by } \\
\text { consultant }{ }^{5} \\
\text { Contractor not adhering to the quality plan } \\
\text { provided by the project }^{6}\end{array}$ & $\begin{array}{l}\text { Chandra, }(2015)^{1} \\
\text { Thuyet et al. }(2007)^{6} \\
\text { Samarah \& Bekr, } \\
(2016)^{2,3,4,5} \\
\text { Umeesh et al., } \\
(2018)^{6}\end{array}$ \\
\hline $\begin{array}{c}\text { Project } \\
\text { Resource } \\
\text { Management }\end{array}$ & $\begin{array}{l}31 . \\
32 . \\
33 . \\
34 . \\
35 . \\
36 . \\
\\
37 . \\
38 . \\
39 . \\
40 . \\
41 . \\
42 .\end{array}$ & $\begin{array}{l}\text { Inadequate design team }{ }^{1} \\
\text { Incompetence of project teams }{ }^{2} \\
\text { Low level productivity by the contractor }{ }^{3} \\
\text { Non-availability of consultant's staff on site }{ }^{4} \\
\text { Client related materials }{ }^{5} \\
\text { Shortage of experienced and qualified } \\
\text { engineers }{ }^{6} \\
\text { Lack of transportation for equipment }^{7} \\
\text { Foreign workers }{ }^{8} \\
\text { Impractical allocation of resources }{ }^{9} \\
\text { Shortage of labours }{ }^{10} \\
\text { Split procurement team }{ }^{11} \\
\text { Lack of suppliers }{ }^{12}\end{array}$ & $\begin{array}{l}\text { Reyadh \& Saad } \\
\qquad(2019)^{1} \\
\text { Thuyet et al. }(2007)^{2} \\
\text { Samarah \& Bekr, } \\
\quad(2016)^{3,4} \\
\text { Umeesh et al., } \\
(2018)^{5,6,7,8,9,10,11,12}\end{array}$ \\
\hline $\begin{array}{c}\text { Project } \\
\text { Communications } \\
\text { Management }\end{array}$ & $\begin{array}{l}43 . \\
44 . \\
45 .\end{array}$ & $\begin{array}{l}\text { Lack of effective communication among } \\
\text { project stakeholders }{ }^{1} \\
\text { Lack of cooperation between client and } \\
\text { contractor }^{2} \\
\text { Virtual communication method }^{3}\end{array}$ & $\begin{array}{l}\text { Reyadh \& Saad } \\
\qquad(2019)^{1} \\
\text { Ruqaishi \& Bashir, } \\
\quad(2013)^{1} \\
\text { Memon et al., } \\
\quad(2014)^{1} \\
\text { Samarah \& Bekr, } \\
(2016)^{2} \\
\text { Umeesh et al., } \\
(2018)^{3}\end{array}$ \\
\hline $\begin{array}{l}\text { Project Risk } \\
\text { Management }\end{array}$ & $\begin{array}{l}46 . \\
47 . \\
48 . \\
49 . \\
50 .\end{array}$ & $\begin{array}{l}\text { Subsurface challenges }{ }^{1} \\
\text { Project teams fail to incorporate the risks in } \\
\text { the planning phase }{ }^{2} \\
\text { Financial risks from lack of project financing }{ }^{3} \\
\text { Financial restrictions on upstream businesses } \\
\text { due to decline in oil price }{ }^{4} \\
\text { Uncertainties of large projects }{ }^{5}\end{array}$ & $\begin{array}{c}\text { Akal, }(2016)^{3} \\
\text { Offshore Magazine, } \\
(2016)^{1,4} \\
\text { Umeesh et al., } \\
(2018)^{2,4,5}\end{array}$ \\
\hline
\end{tabular}




\begin{tabular}{|c|c|c|c|}
\hline $\begin{array}{c}\text { Project } \\
\text { Procurement } \\
\text { Management }\end{array}$ & $\begin{array}{l}55 . \\
56 . \\
57 . \\
58 .\end{array}$ & $\begin{array}{l}\text { Delay in buyback problems due to bidding } \\
\text { process is suspended }{ }^{1} \\
\text { Late in procurement and delivery }{ }^{2} \\
\text { Inadequate tendering practices }{ }^{3} \\
\text { Client using lowest bid that led to low } \\
\text { performance by the contractor }{ }^{4} \\
\text { Contractor selection methods }{ }^{5} \\
\text { Delay in start of purchasing long-lead items }{ }^{6} \\
\text { Inadequate selection of contractors in the } \\
\text { planning and EPC phases }{ }^{7} \\
\text { Unrealistic contract decision-making }{ }^{8}\end{array}$ & $\begin{array}{l}\text { Tippee , }(2017)^{1} \\
\text { Ruqaishi \& Bashir, } \\
(2013)^{2} \\
\text { Salama et al., } \\
(2008)^{2} \\
\text { Ade Asmi et al., } \\
(2019)^{2} \\
\text { Thuyet et al. (2007) } \\
\text { Samarah \& Bekr, } \\
(2016)^{4,7} \\
\text { Umeesh et al., } \\
(2018)^{5,8}\end{array}$ \\
\hline $\begin{array}{c}\text { Project } \\
\text { Stakeholder } \\
\text { Management }\end{array}$ & $\begin{array}{l}61 . \\
62 . \\
63 . \\
64 . \\
65 . \\
66 . \\
67 . \\
68 . \\
69 . \\
70 . \\
71 . \\
72 . \\
73 . \\
74 .\end{array}$ & 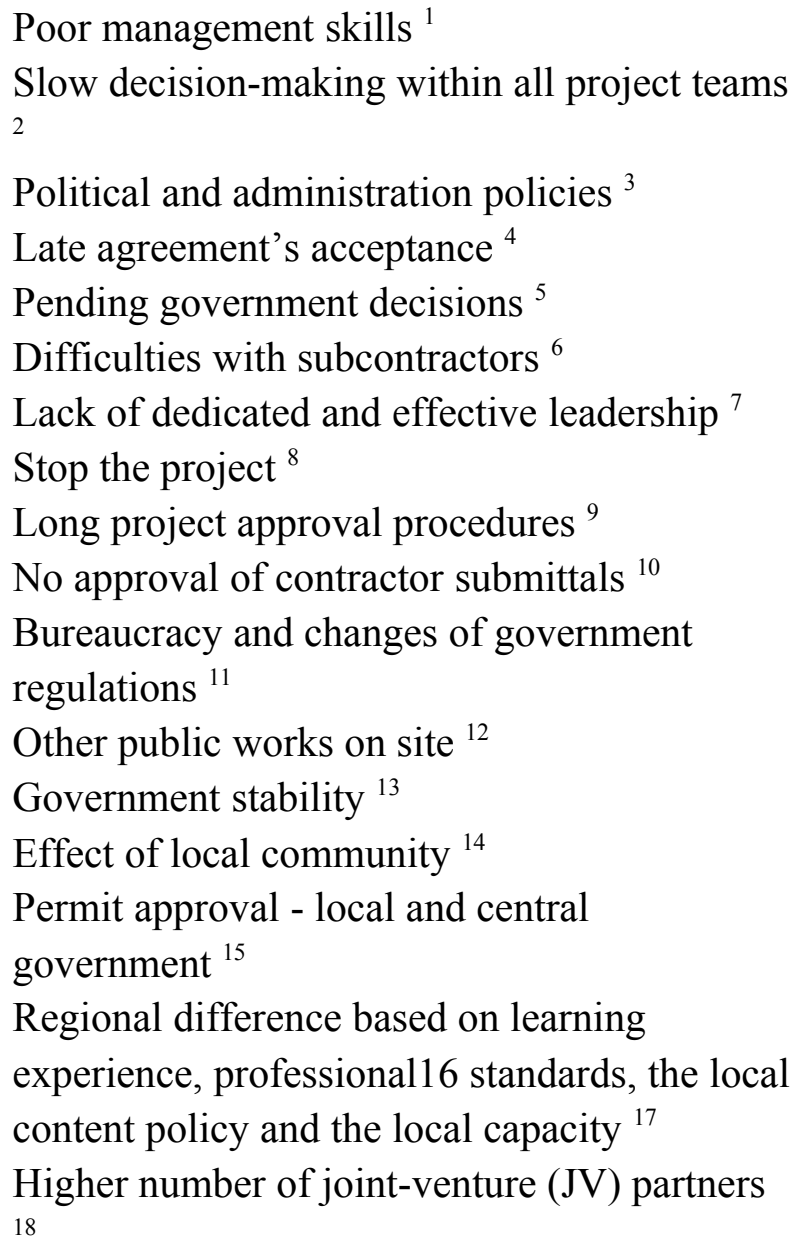 & $\begin{array}{c}\text { Reyadh \& Saad } \\
(2019)^{1,2} \\
\text { Akal, }(2016)^{3} \\
\text { Tippee, }(2017)^{3} \\
\text { Umeesh et al., } \\
(2018)^{4,5,13,15,16,17} \\
\text { Ruqaishi \& Bashir, } \\
(2013) \\
\text { Memon et al., } \\
(2014)^{7} \\
\text { Chandra, }(2015)^{8} \\
\text { Thuyet et al. }(2007)^{9} \\
\text { Samarah \& Bekr, } \\
(2016)^{10,11,12,14}\end{array}$ \\
\hline
\end{tabular}

\subsection{Previous Studies Conducted on Strategies to Mitigate Project Delays}

Previous investigations have suggested numerous strategies to mitigate delays and minimize the impact on project performance. Wang et al. (2004) have proposed relevant mitigation strategies that can be implemented to mitigate many risk events and established a risk management framework that recommends a "proper mitigation strategy based on the country, market, and project risks, respectively". Additionally, the project risk management has been considered as 
"critical method and critical success factor for improving the cost, schedule, and quality management" according to Asadi et al. (2018). Furthermore, mitigation strategies such as "the project mission, top management's intervention, and project scheduling" which have been observed to have consequence on project performance throughout different phases of implementation Asadi et al., 2018). Tripathi and Jha (2018) have also reported total of six (6) success factors for organization to achieve project performance. Those success factors include "top management competence, project factor, experience and performance, supply chain and leadership, effective cost control procedures and availability of resources". And top management competency was ranked the highest among the other success factors. Moreover, knowledgeable project manager, experienced project team, realistic cost throughout project life cycle, commitment of the project stakeholders, and resources availability were recommended as five (5) possible factors that may be implemented to minimalize project delays (Nguyen et al., 2004).

Additionally, other strategies were identified to mitigate project delays include "good presentation of information during tendering, timely payments of completion certificates, workers' motivation and morale, finishing the design on time, good logistic management (Transportation), capacity building training and top management's support". Furthermore, "previous work experience on similar projects, sponsor 'influence, close project management, project's adequate financing and arrangement, suitable time estimation skills, availability and quality of the workers, and availability of materials and equipment were reported as mitigation strategies" (Pinto \& Kharbanda ,1995). Moreover, as reported by Li et al. (2019), in their findings from many reviews of publications starting from 2005 to 2018 and they proposed the success factors include "effective project planning and controlling, owner's involvement and commitment, communication and cooperation, clear goals and objectives".

\subsection{Research Methodology}

In order to organize this research into systemic structure, the research design has been classified into three steps to help the author how the research conducted to achieve the objectives. The first step involves the data collection and analysis from comprehensive literature review and interviews with oil and gas industry experts to determine the relevant factors causing oil and gas project delays. Secondly, preparation and distribution of questionnaire surveys and conduct qualitative analysis on the identified factors impacting oil and gas projects in Malaysia due to COVID-19 pandemic. Lastly, making conclusions from the findings and propose recommendations.

\subsection{Sampling Size for the Distribution of Survey Questionnaire}

The selection of sample size is very significant step in the data collection process and the most effective method to ensure the generality of results is to have a sufficient large sample (Ruqaishi \& Bashir, 2015). According to Miaoulis and Michener (1976), the determination of any sample size should consider three criteria include "level of confidence, level of precision and the degree of variability in attribute of interest". There are approximately 36,776 employees engaged in the oil and gas industry in Malaysia (MAHIDIN, 2019). In this study, the sample 
size of 100 was derived from Yamane's equation 1 based on the actual population engaged in the oil and gas industry in Malaysia. Assumption of $95 \%$ confidence level and $\pm 10 \%$ of margin error used to compute the sample size.

$$
n=\frac{N}{1+N\left(e^{2}\right)}
$$

Equation 1: Sample size simplified formula developed by Yamane (1967)

where

$\mathrm{n}=$ the target sample size

$\mathrm{N}=$ the population size, 36,776 in this case of study

$\mathrm{e}=$ the level of precision, $\pm 10 \%$ in this case

\subsection{Cronbach Alpha Reliability Test}

In order to test if the information used in the questionnaire are reliable, the Cronbach's alpha has been calculated for each of the transform variables include delay factors, rank delay factors and mitigation measures. According to researchers Bryman and Bell. (2011), any data is considered reliable if the Cronbach's alpha of the variables is 0.7 or higher.

Additionally, other researchers such as Hair et al. (2010) suggested that "although a value of 0.70 is commonly agreed as an acceptable value and nevertheless alpha value approximately 0.60 could be satisfactory for exploratory research". Equation 2 illustrates Cronbach Alpha formula.

$$
\alpha=\frac{N \bar{C}}{\bar{v}+(N-1) \bar{C}}
$$

Equation 2: Cronbach Alpha formula by Lee Cronbach (1951)

where

$\mathrm{N}=$ the number of items

$\overline{\mathrm{C}}=$ average covariance between item-pairs

$\overline{\mathrm{V}}=$ average variance

Furthermore, George and Mallery (2003) proposed a "range approach comprising of the following: $\geq 0.9$ - Excellent, $\geq 0.8-$ Good, $\geq 0.7$ - Acceptable, $\geq 0.6-$ Questionable, $\geq 0.5-$ Poor, and $\leq 0.5$ - Unacceptable". Statistical Package for the Social Sciences (SPSS) are employed to determine Cronbach's alpha of all transformed variables.

\subsection{Computation of Relative Importance Index (RII) and Ranking}

As reported by Aibinu \& Jagboro (2002), highlighted that "the Relative Importance Index (RII) method is used to define the relative importance of the particular causes and effects depending on the likelihood of occurrence and consequence on the project using five Likert scale". Additionally, the higher value of the RII the more is the critical cause or impact factor. Relative 
Importance Index (RII) is used for ranking purposes highest to lowest priority. Microsoft excel will be employed to calculate Relative Importance Index (RII) for all variables. Equation 3 is used to determine the Relative Importance Index (RII).

$$
R I I=\frac{\sum W}{(A * N)}
$$

Equation 3: Relative Importance Index (RII)

where

RII = Relative Importance Index

$\mathrm{W}=$ the weight given to each factor by the respondents $(1,2,3,4$ and 5)

$\mathrm{A}=$ the highest weight (i.e., 5 in this case)

$\mathrm{N}=$ the total number of respondents

According to Sambasivan \& Soon (2007), stressed that "the greater the value of RII, the more significant is the cause or delays". Additionally, Akadiri (2011), he has stated Five important levels are transformed from Relative Index values. Table 2 below displays five important levels are transformed from Relative Index values.

Table 1 - Five important levels transformed from Relative Index values (Akadiri, 2011)

\begin{tabular}{|c|c|c|c|}
\hline Relative Importance Index (RII) Value & Importance Level & Level of Agreement & Scale \\
\hline $0 \leq \mathrm{RI}<0.2$ & Low $(\mathrm{L})$ & Strongly Disagree & 1 \\
\hline $0.2 \leq \mathrm{RI}<0.4$ & Medium-Low $(\mathrm{M}-\mathrm{L})$ & Disagree & 2 \\
\hline $0.4 \leq \mathrm{RI}<0.6$ & Medium $(\mathrm{M})$ & Neutral & 3 \\
\hline $0.6 \leq \mathrm{RI}<0.8$ & High-Medium $(\mathrm{H}-\mathrm{M})$ & Agree & 4 \\
\hline $0.8 \leq \mathrm{RI} \leq 1$ & $\operatorname{High}(\mathrm{H})$ & Strongly Agree & 5 \\
\hline
\end{tabular}

\subsection{Descriptive Statistics}

According to Siegel and Castellan (1988), emphasized that "the non-parametric statistics has been considered to be conservative and acceptable method as stated by using a parametric test, the researcher would add information and thereby, create distortions which may be as great and as damaging as those introduced by the throwing away of information". As reported by Pimentel (2010), "If data is considered as ordinal data, Likert responses possibly presented in a graph particularly bar charts". "The center of tendency is the median or the mode but not the mean". Hence, it is important to analyze ordinal data using nonparametric statistics such as median, frequency, and mode (Pimentel ,2010) and (Siegel \& Castellan , 1988). Additionally, the mean and standard deviation are considered inappropriate for ordinal data measurement (Jamieson, 2004). In the current investigation, the median of all variables has been computed by Social Science (SPSS) tool and the median value has been used to interpret all responses submitted by the respondents based on five Likert scale. At the preliminary stages of the data analysis, Statistical Package for the Social Sciences (SPSS) was employed to generate 
descriptive statistics results in order to provide general understandings of the data and followed up with more detailed analysis such as the Cronbach Alpha Reliability test and Relative Importance Index (RII).

\subsection{Result and Discussion}

\subsection{Literature Review Analysis}

Comprehensive literature review was carried out on the available sources of information include published journals, online resources, books and conference papers. Many findings on the factors causing delays were identified from the literature review and analysis was performed to compile the findings and summarize in the table. Based on the results from the literature review, there are approximately 75 identified delay factors which have been conducted by various researchers around the globe. Analysis indicates that most of the studies were conducted to identify factors that caused project delays were not related covid 19 pandemics. Nevertheless, in the current research the author is focusing on identifying and analyzing delay factors due to COVID-19 pandemic. List of delay factors identified from the literature were used as reference and comparison to discuss the findings from the data of survey questionnaires in section $\mathrm{B}, \mathrm{C}$, and $\mathrm{D}$.

\subsection{Focus Group and Individual Interview Analysis}

The interview sessions were organized with various participants from different background and positions. The outcome of the interview sessions showed one participant with more than 20 years working experience in the oil and gas industry. This is very relevant as many of studies conducted require participants to have more working experience in the oil and gas industry. For instance, as reported by Duodu (2016), in this survey questionnaires have requested participants if they have more than 20 years of working experience in the construction.

The outcome also showed that the group have identified and provided many factors which believed to have contributed to the delay of oil and gas projects in Malaysia during COVID-19 crisis. Moreover, the results illustrated mitigation strategies to be considered as proposal for future implementation in the oil and gas industry. The findings from the Focus group and individual interviews were successfully used in the preparation and designing of survey questionnaire for this research and effectively distributed to identified project practitioners in the oil and gas industry in Malaysia. Table 3 illustrate the summary the information compiled from all interviews and appendix A shows summary feedback from all the interview sessions.

Table 2 - Summary of Information Compiled from All Interviewees

\begin{tabular}{|c|c|c|c|}
\hline Interview Type & Position & $\begin{array}{c}\text { Experience in the Project } \\
\text { Management }\end{array}$ & $\begin{array}{c}\text { No. of Years in Oil } \\
\text { and Gas Projects }\end{array}$ \\
\hline $\begin{array}{c}\text { Individual } \\
\text { Interview }\end{array}$ & Program manager (1) & $>26$ years & 20 years \\
\hline $\begin{array}{c}\text { Individual } \\
\text { Interview }\end{array}$ & Project Manager (1) & $15-20$ years & 12 years \\
\hline
\end{tabular}




\begin{tabular}{|c|c|c|c|}
\hline $\begin{array}{c}\text { Focus Group } \\
\text { Interview }\end{array}$ & Project Engineers (3) & 5-10 years & $\begin{array}{c}8 \text { years }(1) \\
6 \text { years }(2)\end{array}$ \\
\hline $\begin{array}{c}\text { Focus Group } \\
\text { Interview }\end{array}$ & \begin{tabular}{c} 
Project Control Manager (1) \\
\cline { 2 - 4 }
\end{tabular} & $>15$ & 10 years \\
\hline $\begin{array}{c}\text { Planning \& Scheduling (2) } \\
\text { Focus Group } \\
\text { Interview }\end{array}$ & Project controllers (5) & $>12$ & $\begin{array}{c}10 \text { years }(1) \\
9 \text { years (1) }\end{array}$ \\
\hline
\end{tabular}

\subsection{Design Of Survey Questionnaire and Analysis}

The outcome from the focus group and individual interviews has analyzed and developed comprehensive set of surveys questionnaires. The analysis of questionnaire was further conducted through survey pilot testing.

The outcome from the pilot test involving 15 respondents showed that the set of design questionnaires were acceptable with minimal amendment to redefine additional questions and rewording some statements for the benefits of other external project stakeholders such as contractors and subcontractors. The objective of this pilot testing is to further assist the author to validate questionnaire to ensure comprehensiveness to achieve the research objectives. The survey questionnaire was distributed to more than 150 participants in order to meet the minimum requirement. Additionally, the survey questionnaire consists of different sections. There are total of 12 questions in section $\mathrm{B}, \mathrm{C}$ and $\mathrm{D}$ respectively. The participants were asked to select each question based on 5 Likert scale. All questions were designed and developed from the findings of the interview sessions. The survey result showed total of 110 respondents have participated in the survey.

\subsection{Organization Type and Job Designation}

From Figure 2 the chart states that the majority of participants are from clients or owners' side with $47.3 \%$ equivalent to 52 respondents. This result is reasonable as many oils and gas project are undertaken by project owners. Additionally, followed by consultant about $22.7 \%$ corresponding to 25 participants. Approximately, 20.9\% equivalent to 23 respondents have been recorded as contractors and another $4.5 \%$ correspond to 5 respondents who have participated as subcontractors.

Furthermore, $2.7 \%$ equivalent to 3 participants have been recorded as vendor or supplier and another two (2) insignificant figures about $0.9 \%$ each equivalent to 1 participant have recorded as utility company and operating company respectively.

The outcome from figure 3 chart demonstrates that there are $20 \%$ equivalent to 22 participants recorded as project engineers. $17.3 \%$ correspond to 19 respondents have participated as project managers. Moreover, $14.5 \%$ equivalent to 16 people have been recorded as technical professional who are dealing the project cost and schedule. Another $13.6 \%$ correspond to 15 
participants have submitted the survey as project control engineer who are dealing with project cost and schedule. The remaining of participants include engineering managers $(4.5 \% \sim 5$ people), procurement managers $(5.5 \% \sim 6$ people), discipline engineers $(7.3 \% \sim 8$ people), frontend technical profession and front-end engineers $(4.5 \% \sim 5$ people $)$, program managers $(2.7 \% \sim 3$ people) and about $0.9 \%$ each for the rest of discipline.

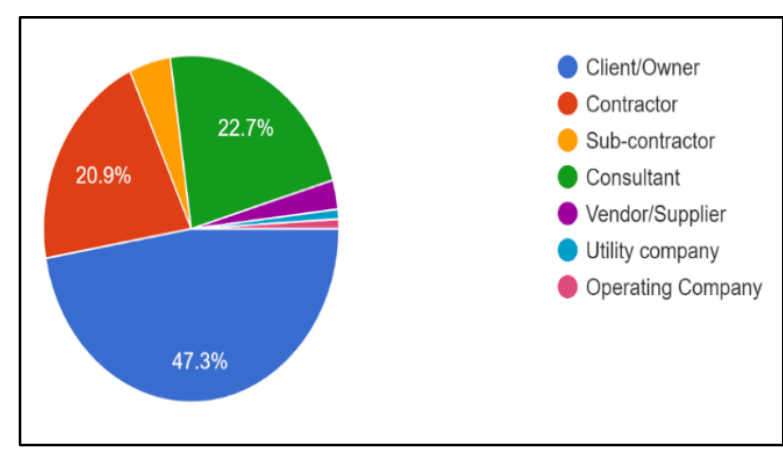

Figure 1 - Organization Type

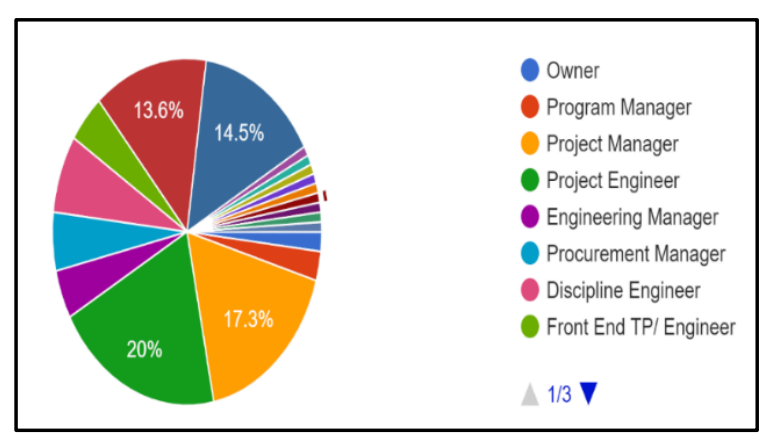

Figure 2 - Job Designation of the Participants

\subsection{Years of Working Experience And Job Responsibility}

The figure 4 indicates that the majority of respondents have average experience between $11-$ 15 years working in the oil and gas project. This is equivalent to $40.9 \% \sim 45$ participants from total sample of 100 of this research. $30.9 \%$ correspond to 34 respondents have working experience between 16-25 years. Additionally, 12.7\% 14 participants have been recoded with working experience between 6-10 years. 9.1\% 10 people have working experience between 0-5 years and another $6.4 \% \sim 7$ participant who have more than 26 years of working experience in the oil and gas industry in Malaysia. This result is considered reliable input and it will assist in the identification of delay factors and analysis as they are mixed of participants from different background and working experience.

The chart in figure 5 displays about $70.9 \%$ equivalent to 78 participants who have been working in the project management. $15.5 \%$ correspond to 17 people who execute their jobs under engineering discipline. 5.5\% equivalent 6 respondents who are working under procurement discipline while $3.6 \%$ correspond to 4 participants who are undertaking construction. The remaining are participants who are working under different discipline include QAQC, HSE, auditor, project scheduler, and project control.

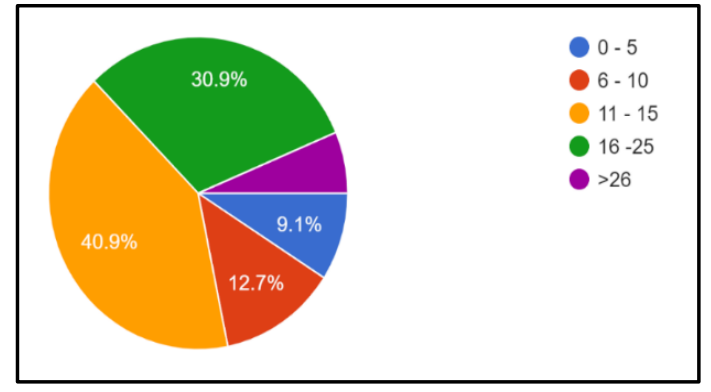

Figure 3 - Working experience

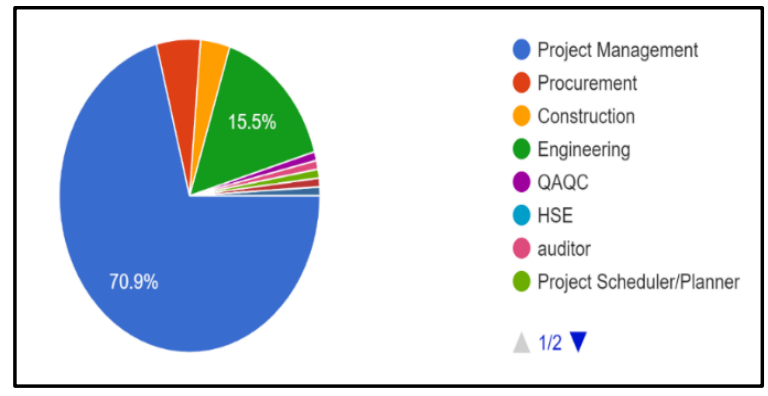

Figure 4 - Job responsibility in the company 


\subsection{Reliability Test}

The Overall reliability test for all section Questions was computed by SPSS tool and the found value for the Cronbach's Alpha is $0.942 \sim 94.2 \%$. This result indicates that the value is greater than the minimum Cronbach's Alpha required which is 0.7 (Bryman \& Bell, 2011). The outcome from this study shows that all variables have met the minimum requirement of the Cronbach's alpha and can be concluded that the information used in the questionnaire are considered reliable data and valid.

\subsection{Seven (7) Top Delay Factors Impacting Oil and Gas Projects in Malaysia during COVID- 19 Crisis}

In this section (B), the objective was to engage oil and gas project practitioners to assess the level of agreement on the delay factors and its impact on oil and gas projects in Malaysia due to COVID-19 pandemic. The feedback submitted by 110 respondents were based on the five Likert scale and was analyzed according to the median of each factor computed by SPSS and the Relative Important Index was calculated by the excel sheet. Calculated RII values have been used to rank the factors. Table 4 shows result of top seven (7) delay factors and its impact.

Table 2 Result of Top Seven (7) Delay Factors and its Impact

\begin{tabular}{|l|c|c|c|}
\hline \multicolumn{1}{|c|}{ Delay Factors } & Median & RII & Rank \\
\hline Low productivity due to frequent disruption (B7) & 4.00 & 0.862 & 1 \\
\hline $\begin{array}{l}\text { Impact on overall project schedule due to late delivery of critical } \\
\text { equipment and material caused by border restriction (B2) }\end{array}$ & 4.00 & 0.849 & 2 \\
\hline $\begin{array}{l}\text { Low productivity due to the limitation of workforce is significantly } \\
\text { reduced in order to adhere to social distancing measures, travel } \\
\text { restrictions, and safety precaution (B8) }\end{array}$ & 4.00 & 0.847 & $\mathbf{3}$ \\
\hline $\begin{array}{l}\text { Impact on project schedule due to quarantine requirement - 14 days } \\
\text { before entering to construction site which led to extension of time } \\
\text { (B3) }\end{array}$ & 4.00 & 0.844 & $\mathbf{4}$ \\
\hline $\begin{array}{l}\text { Delay in project due to difficulty in making appointment with local } \\
\text { authority (B11) }\end{array}$ & 4.00 & 0.836 & $\mathbf{5}$ \\
\hline $\begin{array}{l}\text { Project delay due to limited availability of shipping vessels and } \\
\text { congestion at delivery points caused longer retrieval of equipment } \\
\text { and material (B6) }\end{array}$ & 4.00 & 0.833 & $\mathbf{6}$ \\
\hline $\begin{array}{l}\text { Delay in mobilizing Vendor Field Service Representative (FSR) to } \\
\text { site to manage commissioning works (B10) }\end{array}$ & 4.00 & 0.829 & $\mathbf{7}$ \\
\hline
\end{tabular}

\section{- Low productivity due to frequent disruption (B7)}

From the table 4.4 above, the result from statement (B7) expresses that out of 110 participants there are 50 respondents $(45.5 \%)$ have shown strongly agree level with median $=4$ and RII $=$ 0.862 . Hence, low productivity due to frequent disruption is valid factor to consider and it has 
high negative impact on the projects. A low productivity is common factor that causing project delay. This type of delay can be minimized by having different strategies in place and ready to be implemented when there is disruption.

- Impact on overall project schedule due to late delivery of critical equipment and material caused by border restriction (B2)

While the outcome from the second statement (B2) states that 52 respondents $(47.3 \%)$ have selected for agree level with the median $=4$ and RII $=0.849$ which translates that most of the participants have approved that this delay factor has high negative impact. Late in procurement and delivery has also been reported as one of major cause of delay in oil and gas project (Salama et al.,2008). Furthermore, late delivery of equipment has been listed top delay factors in construction industry (Ade Asmi et al., 2019) and (Sambasivan \& Soon ,2007). This type of delay factor can be mitigated trough proper detailed planning and early identification of critical equipment and material.

- Low productivity due to the limitation of workforce is significantly reduced in order to adhere to social distancing measures, travel restrictions, and safety precaution (B8)

The result from statement (B8) shows that 49 respondents (44.5\%) have revealed strongly agree level with median $=4$ and RII $=0.847$. Therefore, it is relevant factor with high negative impact on projects. Additionally, researchers such as Samarah \& Bekr (2016) and Sambasivan \& Soon (2007) have also reported that low productivity is one of the top delay factors in oil and gas projects. It can be mitigated by having more workforces who are available to execute critical activities.

- Impact on project schedule due to quarantine requirement - 14 days before entering to construction site which led to extension of time (B3)

The outcome from the statement (B3) shows 48 participants (43.6\%) have selected for strongly agree level with median $=4$ and RII $=0.844$. This is also important factor with significant negative impact on the project. The mitigation of this delay is to ensure workforce is located near the project site and negotiate with local authority on quarantine requirement.

- Delay in project due to difficulty in making appointment with local authority (B11)

Additionally, the finding from statement (B11) shows that 50 respondents (50\%) have opted for agreed level with median $=4$ and RII $=0.836$. Hence, the participants have evaluated that this factor has high negative impact on the oil and gas project. This type of delay can be mitigated trough early and frequent engagement with local authority to ensure inspection is conducted in timely manner.

- Project delay due to limited availability of shipping vessels and congestion at delivery points caused longer retrieval of equipment and material (B6)

The outcome from the statement (B6) illustrates those 48 participants (43.6\%) have chosen for agreed level with median $=4$ and RII $=0.833$. Hence, the respondents have assessed that this factor has high negative impact on the oil and gas project. Availability of critical equipment is 
very success favor for meeting project objective. Therefore, it is important to re-strategize on different route for procurement of critical equipment.

\section{- Delay in mobilizing Vendor Field Service Representative (FSR) to site to manage commissioning works (B10)}

Whereas the finding from statement (B10) explains that 46 people (41.8\%) have opted for agreed level with median $=4$ and $\mathrm{RII}=0.829$. Most of the participants have selected for agree level which has been confirmed with median value and its impact level with RII value accordingly. This delay can be reduced by leveraging on the local vendor field service who is competent for managing commissioning activities.

\subsection{Top Potential Mitigation Strategies}

In this section (D), the main objective was to engage oil and gas project practitioners to assess the level of agreement on the delay factors and its impact on oil and gas projects in Malaysia due to COVID-19 pandemic. The feedback submitted by 110 respondents based on the five Likert scale and analyzed based on the median of each factor computed by SPSS and the Relative Important Index was calculated by the excel sheet. The calculated RII values have been used to rank the factors. Table 5 displays outcome of top 7 mitigation strategies.

Table 3 - Outcome of Top 7 Mitigation Strategies

\begin{tabular}{|l|c|c|c|}
\hline \multicolumn{1}{|c|}{ Mitigation Strategies } & Median & RII & Rank \\
\hline $\begin{array}{l}\text { Change in mindset, leadership and adopting new cultural principles } \\
\text { (D2) }\end{array}$ & 5.00 & 0.945 & 1 \\
\hline $\begin{array}{l}\text { Resilience and innovation are essentials for business continuity and } \\
\text { sustainability (D1) }\end{array}$ & 5.00 & 0.940 & 2 \\
\hline $\begin{array}{l}\text { Collaboration with stakeholders and partners during project execution } \\
\text { to improve progress (D9) }\end{array}$ & 5.00 & 0.931 & $\mathbf{3}$ \\
\hline Resilience in project controls and project delivery (D5) & 5.00 & 0.925 & $\mathbf{4}$ \\
\hline $\begin{array}{l}\text { Introducing agile project management philosophy as the mitigation } \\
\text { strategy (D11) }\end{array}$ & 5.00 & 0.916 & $\mathbf{5}$ \\
\hline $\begin{array}{l}\text { Early identification and issuance of purchase order (PO) for critical } \\
\text { equipment to improve manufacturing and delivery time (D3) }\end{array}$ & 5.00 & 0.913 & $\mathbf{6}$ \\
\hline $\begin{array}{l}\text { Oil and gas companies to implement digital transformation and } \\
\text { solutions to maintain project continuity (D6) }\end{array}$ & 5.00 & 0.911 & $\mathbf{7}$ \\
\hline
\end{tabular}

- Change in mindset, leadership and adopting new cultural principles (D2)

From the table 4.5 above, the result from the second statement (D2) shows that out of1 10 participants there are 84 respondents (76.4\%) have selected for strongly agree level with median $=5$ and $\mathrm{RII}=0.945$. The majority of the participants have chosen for strongly agree level which have been validated with RII and median. Thus, this proposed mitigation strategy is 
very significant and has high impact on project. Tripathi and Jha (2018) have also reported that leadership is one the success factors for organization to achieve project performance.

\section{- Resilience and innovation are essentials for business continuity and sustainability (D1)}

The outcome from the first statement (D1) indicates that 77 respondents (70\%) have opted for strongly agree level with median $=5$ and RII $=0.940$. Hence, this shows that the proposed mitigation plan is extremely acceptable with positive impact on project. Oil and gas companies should be more resilient and innovative enough tin order to excel in the business continuity and sustainability.

\section{- Collaboration with stakeholders and partners during project execution to improve progress} (D9)

Furthermore, in the statement (D9), the result states that 77 participants corresponding to $70 \%$ have chosen for strongly agree level with median $=5$ and $\mathrm{RII}=0.931$. As reported by Aris et al., (2015), collaboration is very important skill in the working world. Thus, the result indicates that this proposed mitigation strategy is extremely recommended and has high positive impact on oil and gas projects. Oil and gas industry should collaborate with different project stakeholders include contractors, consultants, JV partners, local authority, local community and project team members.

\section{- Resilience in project controls and project delivery (D5)}

The finding from the statement (D5) shows that 73 people $(66.4 \%)$ have selected for strongly agree level with median $=5$ and $\mathrm{RII}=0.925$. Hence, the result expresses that this proposed mitigation strategy is extremely suitable with high impact. It is very critical for oil and gas industry to be more resilience in project controls and project delivery. Resilience in project controls include creating different tools and technology to control projects. Additionally, oil and gas companies should continuously improve project delivery include optimization of internal processes, implement best project practices and retooling of human resources.

\section{- Introducing agile project management philosophy as the mitigation strategy (D11)}

The outcome from the question (D11) displays that 72 people (65.5\%) have indicated for strongly agree level with computed value of median $=5$ and RII $=0.916$ respectively. This signifies that the result has confirmed the proposed mitigation strategy is very significant with high positive impact on project. Oil and gas companies should introduce agile concept in the project management. Nowadays, agile approach has been implemented by information and technology (IT) industry.

- Early identification and issuance of purchase order (PO) for critical equipment to improve manufacturing and delivery time (D3)

The result from statement (D3) demonstrates that out of 110 respondents there are 76 individuals $(69.1 \%)$ have opted for strongly agree level with median $=5$ and RII $=0.913$. Therefore, the result demonstrates that this proposed mitigation strategy is very essential with high impact. As also stated by Pinto \& Kharbanda (1995), that availability of materials and 
equipment are proven mitigation strategies. Oil and gas project practitioners should early identify critical equipment and early planning for issuing purchase order (PO). This type of strategy will further optimize the schedule and meeting the project objective.

\section{- Oil and gas companies to implement digital transformation and solutions to maintain project continuity (D6)}

In the statement (D6), the result indicates that 69 individuals $(62.7 \%)$ have showed strongly agree level with median $=5$ and $\mathrm{RII}=0.911$. Hence, the result illustrates that this proposed mitigation strategy is equally important with high positive impact on oil and gas projects. During COVID-19 many oil and gas companies around the globe have embracing digital transformation as the only solution for project continuity. Hence, it is very significant approach to implement digital in oil and gas projects.

\subsection{Conclusion}

Oil and gas industry comprises various big-scale construction projects ranging from exploration to production and from pipelines to storage tanks as well as refineries and petrochemicals. This research has investigated the delay factors that have caused impacts on oil and gas projects in Malaysia due to COVID-19 pandemic. Total of 75 factors causing delays were identified that reported by various researchers around the globe. Analysis from literature revealed that most delay factors were not caused by covid 19. In the current research, few delay factors were found to have similarity with literature review finding. Furthermore, interview sessions were organized with oil and gas professionals in Malaysia.

110 respondents who have participated in the survey questionnaires and the result from the analysis showed that the majority of respondents have indicated strong agreement level on the delay factors and mitigation strategies. Top seven (7) delay factors identified, it is observed that low productivity due to frequent disruption (1) has highly impacted oil and gas projects in Malaysia. Followed up with the impact on overall project schedule due to late delivery of critical equipment and material caused by border restriction (2), this indicates that critical equipment and material are important to deliver in timely manner to avoid negative impact on the project schedule. Additionally, low productivity due to the limitation of workforce (3) is another common factor faced in projects and it has highly impacted the projects due to limiting workers to comply with SOPs. Moreover, the quarantine requirement (4) and making appointment with local authority (5) have both listed as delay factor and significantly have impacted projects schedule. Furthermore, project delays due to limited availability of shipping vessels and congestion at port due to lack of logistic arrangement (6) and management during COVID-19 pandemic. Mobilizing Vendor Field Service Representative to manage commissioning activities (7) has also significantly impact project schedule and the main reason it is due to travel restriction. All delay factors are recommenced to closely monitored and mitigated accordingly to avoid or minimize negative impact on project.

From the proposed top seven (7) mitigation strategies listed above, it is clearly indicating that change in mindset, leadership and adopting new cultural principles (1) is very important for 
project to succeed. Leadership is one the success factors for organization to achieve project performance. Additionally, resilience and innovation (2) are equally significant for business continuity and sustainability. Oil and gas companies are required to be more resilient and innovative in moving forward during crisis. Furthermore, another important project success factor is collaboration with stakeholders and partners (3). Oil and gas companies are required to be more resilience in project controls and project delivery (4). Change in project controls strategies may require to overcome negative impacts due to challenges of COVID-19. Agile project management concept (5) is highly recommended to implement in the oil and gas industries as nowadays. It is also important to note that oil and gas companies to early identify the critical equipment and material and anticipate issuance of purchase order (PO) to improve manufacturing and delivery time (6) that can expediate project schedule. Oil and gas companies are highly recommended to implement digital transformation (7) as only solutions to sustain company and project continuity. Since the beginning of COVID-19, many organizations around the world regardless of their type, they have been transforming into digital companies.

\subsection{Limitations and Future Work}

Due to the situation of COVID- 19 pandemic many difficulties have been faced while completing this research, the majority of research activities were performed virtually and time consumption for data collection include interviews and survey. It is recommended to conduct investigation on project delay factors involving other construction industries not limited only to oil and gas companies in Malaysia. Not involving other construction industries may cause gaps in the study due to not manage to document the perception about the causes of delays.

\subsection{Acknowledgment}

Special thanks and gratitude to all oil and gas professionals who have involved directly and indirectly in completing this investigation on analysis of delay impact of COVID-19 pandemic on Malaysian's oil and gas projects. Additionally, special and humble gratitude to project supervisor Ts. Dr. Zulhasni Abdul Rahim for continuous and endless guidance in completing this project.

\subsection{References}

1. Aditi Dinakar, 2014, Delay Analysis in Construction Project. IJETAE, Volume 4, Issue 5

2. Aibinu A.A. Jagboro G. O., 2002, The effects of construction delays on project delivery in Nigerian construction industry. International Journal of Project Management, 20 (8), 593599

3. Akadiri O. P., 2011, Development of a Multi-Criteria Approach for the Selection of Sustainable Materials for Building Projects, PhD Thesis, University of Wolverhampton, Wolverhampton, UK

4. Aris Zak, Valentine Jofranklin, Mohamad Fairuz, 2015, Project Management In Oil And Gas Industry Context (Oil \& Gas Companies And Contractors)

5. Asadi P., Zeidi J. R., Mojibi T., Yazdani-Chamzini A., Tamošaitien J., Project risk evaluation by using a new fuzzy model based on Elena guideline. J. Civ. Eng. Manag. 2018, 24, 284-300 
6. Asmi Ade, Djamaris Aurino, Ihsan Mohammad, 2019, Top Ten Similarity Ranking for Project Delay Factors in Construction Industry, IOP Conference Series: Materials Science and Engineering, 650, 012006, DOI: 10.1088/1757-899X/650/1/012006

7. Bryman A., Bell E., 2011, Business Research Methods, 2nd edition, Oxford University Press Inc

8. Choudhary S., 2020, April 7, Lockdown to delay several oil, gas projects, The Economic Times, https://economictimes.indiatimes.com/industry/energy/oil-gas/lockdown-to-delayseveral-oil-gas-projects/articleshow/75016382.cms

9. COVID-19: Governance: Impact of Malaysia's Movement Control Order On Your Business (Malaysia), https://www.herbertsmithfreehills.com/latest-thinking/covid-19governance-impact-of-malaysia $\% \mathrm{E} 2 \% 80 \% 99 \mathrm{~s}$-movement-control-order-on-your-business

10. Cronbach's Alpha: Simple Definition, Use and Interpretation, 2021, March 2, Statistics How To, https://www.statisticshowto.com/probability-and-statistics/statistics-definitions/ cronbachs-alpha-spss/

11. Dr. Yaser Gamil, Abdulsalam Alhagar, 2020, The Impact of Pandemic Crisis on the Survival of Construction Industry: A Case of COVID-19 , DOI: $10.36941 / \mathrm{mjss}-2020-0047$

12. Duodu Asiedu Alex, 2016, Management of Delays in Construction Projects in Bia West District

13. ET EnergyWorld, 2020, April 30, Malaysia's Sapura sees delay in energy projects as pandemic hits demand, https://energy.economictimes.indiatimes.com/news/oil-and-gas/malaysias-sapura-seesdelay-in-energy-projects-as-pandemic-hits-demand/75464872

14. George D., Mallery P., 2003, SPSS for Windows step by step: A simple guide and reference, 11.0 update (4th ed.), Boston: Allyn \& Bacon

15. Hair J. F., Black W. C., Babin B. J., Anderson R. E., 2010, Multivariate data analysis: Pearson College Division

16. Harry N. Boone Jr., Deborah A. Boone, 2012, Analyzing Likert Data. Journal of Extension, Volume 50, Number 2

17. Hibiscus taking protective measures offshore Malaysia, UK, 2020, https://www.offshoremag.com/business-briefs/coronavirus/article/14175236/hibiscus-petroleum-takingprotective-coronavirus-measures-offshore-malaysia-uk

18. Issaka Ndekugri, Nuhu Braimah, Rod Gameson, September 2008, Delay Analysis Within Construction Contracting Organizations, Journal of Construction Engineering and Management, Vol. 134, Issue 9, DOI: 10.1061/(ASCE)0733-9364(2008)134:9(692)

19. Jamieson S., 2004, Likert scales: how to abuse them Blackwell Publishing Ltd Medical Education, 2004, 38, 1212-1218

20. Kazemi Aliyeh, Katebi Ali, Kazemi Mohammad-Hossein, 2018, Identifying causes of delay in oil and gas construction projects using fuzzy delphi method

21. Li Y., Song H., Sang P., Chen P. H., Liu X., Review of Critical Success Factors (CSFs) for green building projects, Build. Environ. 2019, 158, 182-191

22. Dr. Mohd Uzir Mahidin, 2019, Department of Statistics Malaysia Official Portal. Annual Economic Statistics 2018: Mining of Petroleum and Natural Gas. Retrieved from https://www.dosm.gov.my/v1/index.php?r=column/cthemeByCat\&cat=96\&bul_id=T1NY 
UmJQUEhycGplR2VXbi9mSzV0UT09\&menu id=TXdvYTlvQXVlTFhVOUJ6NVVES VBNUT09

23. Malaysia Oil \& Gas Q1 2021, 2020, December 1, https://www.marketresearch.com/Business-Monitor-International-v304/Malaysia-Oil-GasQ1-13842119/

24. Malaysia Oil and Gas Market Report with COVID-19 impact Analysis (2020-2025), 2020, Global Monitor. https://www.globalmonitor.us/product/malaysia-oil-and-gas-market-report

25. Miaoulis George, R. D. Michener, 1976, An Introduction to Sampling. Dubuque, Iowa: Kendall/Hunt Publishing Company

26. Nguyen L. D., Ogunlana S. O., Lan D. T. X., A study on project success factors in large construction projects in Vietnam, Eng. Constr. Arch. Manag, 2004, 11, 404-413

27. Paganie D., Report finds nearly $\$ 230$ billion in oil and gas projects deferred, 2016, Offshore Magazine

28. Pinto J. K., Kharbanda O. P., Successful Project Managers Leading Your Team to Success, Van No Strand Reihnhold, New York, NY, USA, 1995

29. Reuters, 2020, April 13, Malaysias Petronas warns of project delays, aims to keep local capex, https://www.firstpost.com/business/malaysias-petronas-warns-of-project-delaysaims-to-keep-local-capex-8256581.html

30. Reyadh M. M. Mohammed, Saad M. A. Suliman, 2019, Delay in Pipeline Construction Projects in the Oil and Gas Industry: Part 1 (Risk Mapping of Delay Factors). International Journal of Construction Engineering and Management 2019, 8 (1), 24-35, DOI: 10.5923/j.ijcem.20190801.04

31. Ruqaishi Mohammed, Bashir Hamdi, 2015, Causes of Delay in Construction Projects in the Oil and Gas Industry in the Gulf Cooperation Council Countries: A Case Study, Journal of Management in Engineering, 31 (3), DOI: 10.1061/(ASCE)ME.1943$\underline{5479.0000248}$

32. Samarah D. A., Bekr D. G., 2016, Causes and Effects of Delay in Public Construction Projects in Jordan

33. Sambasivan M., Soon Y. W., 2007, Causes and effects of delays in Malaysian construction industry, Int. J. Proj. Manag., 25 (5), 517-526

34. Siegel S., Castellan J. N., 1988, Nonparameteric Statistics for the Behavioural Sciences, 2nd Ed., McGraw-Hill, New York

35. Simms L. J., Zelazny K., Williams T. F., Bernstein L., 2019, Does the Number of Response Options Matter? Psychometric Perspectives Using Personality Questionnaire Data. Psychological Assessment, 1-9

36. The financial impact of COVID-19, 2020, May 5, Deloitte Malaysia. https://www2.deloitte.com/my/en/pages/financial-advisory/articles/financial-impact-ofcovid-19.html

37. Tripathi K. K., Jha K. N., Determining Success Factors for a Construction Organization: A Structural Equation Modeling Approach, J. Manag. Eng., 2018, 34

38. Umeesh Kumar, Suppramaniam S, Ismail Syuhaida, Suppramaniam Subaashnii, Causes of delay in the construction phase of oil and gas projects in Malaysia. International Journal of Engineering \& Technology, [S.1.], v. 7, n. 2.29, p. 203-209, May 2018, DOI: 
$\underline{10.14419 / i j e t . v 7 i 2.29 .13318}$

39. University of St Andrews, Likert scale, https://www.st-andrews.ac.uk/media/ceed/students/mathssupport/Likert.pdf

40. Wang S. Q., Dulaimi M. F., Aguria M. Y., Risk management framework for construction projects in developing countries, Constr. Manag. Econ, 2004, 22, 237-252

41. Warner M., 2020, November 24, Scope and the Triple Constraints of Quality-Time-Cost, https://www.theprojectmanagementblueprint.com/blog/project-overview/scope-and-thetriple-contraints-of-quality-time-cost

42. Yamane Taro, 1967, Statistics, An Introductory Analysis, 2nd Ed., New York: Harper and Row 